\title{
The Evolution of Marshall Sahlins
}

\author{
Michael Goldsmith
}

Social Stratification in Polynesia, by Marshall D. Sahlins.

Seatle: University of Washington Press, 1958.

Historical Metaphors and Mythical Realities: Structure in the Early History of the Sandwich Islands Kingdom, by Marshall D. Sahlins. Ann Arbor: University of Michigan Press, 198I (as ASAO [Association for Social Anthropology in Oceania] Special Publication no. I).

Marshal L Sahins (born 1930), the Charles Grey Distinguished Professor at the University of Chicago, is the highest-profile American anthropologist currently working in the field of Oceania. There is no denying his influence in theoretical areas of concern to the discipline as a whole but his final reputation is likely to rest on a number of writings on Pacific topics. Because he is an accomplished archival researcher as well as a fieldworker, his scholarship transcends anthropology and spills over into history, greatly increasing the impact his ideas have had in contemporary intellectual life.

Sahlins's main writings on the Pacific can be divided roughly into two chronological stages: those from the first phase of his work (midI950s to the mid-I970S), where his interests were broadly comparative, materialist, and evolutionist; and those from the subsequent phase (mid-late I970s to the present), where his interests have stemmed from a historically informed ("processual") structuralism. Social Stratification in Polynesia, which stems from the earlier period, started life as his Ph.D. dissertation from Columbia University and became his first book (though its publication was delayed for some time). The seminal book from the later period, Historical Metaphors and Mythical Realities, was published in 1981 but had its genesis as an invited lecture to the I979 gathering of the Association for Social Anthropology in Oceania. It is 
arguably his most controversial work and led to a famous debate with Princeton-based Sri Lankan anthropologist, Gananath Obeyesekere, which will be discussed toward the end of this essay.' Even before Obeyesekere's counterstrike, however, Historical Metaphors had spawned a larger critical and exegetical literature in response than Social Stratification and it continues to do so.

Historical Metaphors was the fruit of some earlier rethinking, in which the pivotal text in Sahlins's transition was Culture and Practical Reason (1976). In that book, Sahlins argued that the unproblematic distinction between nature (or environment) and culture, on which his earlier theory of adaptation depended, was itself a cultural one. This change in theoretical orientation was not directly mirrored by a change of political orientation. Sahlins has positioned himself throughout his career as a leftist intellectual. As a relatively junior academic, he opposed U.S. involvement in Vietnam, in mid-career he wrote a stinging attack on the conservative ideology of sociobiology, and more recently he has poured scorn on economist versions of development and dependency theory. ${ }^{2}$ But the tone of his politics has shifted, from a straightforwardly materialist and progressive view of history to a more reactive and melancholy defense of local cultures against world systems. This is despite the fact that he eschews what he parodies as "despondency theory" (his term for dependency theory) as well as the more demoralizing and depoliticizing tendencies of postmodernism.

\section{Social Stratification in Polynesia}

I first encountered Social Stratification in 1968 as an undergraduate stuclent of anthropology at the University of Auckland, where it was a required text for the second-year course on Polynesia. Of most direct relevance to local ethnographers was Sahlins's essay in formulating a theory of atoll social organization, a topic discussed in only two of the book's chapters ( 5 and II). His discussion of these small-scale societies was based solely on the flimsy documentary evidence available to him in the $19505,{ }^{3}$ but a decade later his ideas were helping to make sense of much richer data emerging from fieldwork undertaken in Tokelau by two Auckland lecturers, Antony Hooper and Judith Huntsman. ${ }^{4}$

Interestingly, by the time of Social Stratification's delayed appearance as a monograph, Sahlins himself had carried out fieldwork not in Polynesia as conventionally defined but in Fiji on the island of Moala 
during 1954 and $19555^{5}$ In one of Social Stratification's more cautious footnotes, he simply noted that on the basis of that field research "no facts were encountered that would seriously challenge the major hypotheses developed here" (xiii). This note displays two traits he later disowned: the scientific ethos in vogue at the time and the flatness of the prose that embodied it.

The hypotheses that guided the documentary research of Social Stratification stemmed from a distinction that Sahlins made between two cross-cutting aspects of social stratification. The first aspect is the degree of stratification, that is, the complexity of the system or the number of different kinds of ranks. The second is the form of stratification, that is, the sociological principles that underlie rank. Other factors being constant, the first aspect, degree, varies directly with productivity, where differences in rank are associated with "differences in function in the process of the distribution of goods. Everywhere in Polynesia, the chief is the agent of general tribal-wide distribution" (xi). On the basis of degree of stratification, Sahlins felt justified in classifying Polynesian societies into three groups: first, the most stratified (Hawai' $i$, Tonga, Samoa, and Tahiti); second, a complex group of less stratified societies that was itself split into two, comprising Mangareva, Mangaia, Easter Island, and Uvea (Wallis) on the one hand and the Marquesas, Tikopia, and Futuna on the other; and finally the comparatively unstratified atolls of Pukapuka, Ontong Java, and Tokelau.

The second aspect, form, underpinned a threefold categorization of Polynesian social structures. The first two such types were to be found on high islands: the ramage system, where high productivity was associated with widespread dispersal of resources, and the descent-line system, where those zones were spatially concentrated. "A ramage . . . is a nonexogamous, internally stratified, unilineal ... descent group" (I 40 ) and the societies organized on this basis "can usually be analyzed as composed of sections of a single genealogical system [i.e., a large-size ramage] at the apex of which stands the paramount chief" (I4I). Most of the case studies Sahlins examined were of this type (e.g., Hawai $i$, Tonga, Tahiti, Tikopia, Marquesas, Mangareva, Mangaia, and Easter Island).

The second type of social structure, the descent-line system, had not previously been discerned as a distinct category. Societies based on this system downplayed the importance of seniority based on pure patrilineal descent and instead reflected strongly localized, flexible, and ambilineal tendencies. Sahlins offered Samoa, Futuna, and Uvea as examples. 
The significance of the distinction between these two kinds of social structure was that they possibly represented adaptive alternatives (2OI). To put it very simply, ramified systems operated where there was "a variety of scattered resource zones" that no single extended family could exploit effectively, thus leading to a kind of specialization (e.g., between coastal and inland groups) that linked them through exchanges based on genealogical connections. Descent-line systems, by contrast, would be expected "where resource areas are clustered in time and space so that a single familial group could cope adequately with the total range of available exploitative techniques" (203).

The third type of social structure encompassed the aforementioned atolls, where social organization was often historically derived from the first two but was, in any event, constrained by the resource poverty and low productivity of the atoll environment. Lack of economic surpluses encouraged a more egalitarian system but (perhaps unexpectedly) one that tended over time to become more intricate than those of the high islands. "Adaptation in social organization would move toward a multiplicity of social groups, each connected with a given productive activity or exploitation of a particular area, and to each of which every individual belongs" (236).

Sahlins summarized his arguments in a final brief chapter that trumpeted the validity of his generalizations "respecting the variable relationship between social stratification and organization and the technological adaptation of culture to the environment" (253). He urged others to develop and test the concept of adaptation. These themes loomed large in the materialist and evolutionist anthropology of the mid-twentieth century in the United States in the writings of Marvin Harris, Morton Fried, and Leslie White, all of whom Sahlins acknowledged as influences $(v)$.

It is fair to say that contemporary reviewers who stood outside the evolutionist tradition received Social Stratification with more respect than enthusiasm, but at least the editors who commissioned them did Sahlins the honor of asking recognized authorities to subject his book to critical scrutiny. Among these leading scholars, Ian Hogbin and Ward Goodenough both found the hypothesized link between productivity and stratification unconvincing but praised Sahlins for providing a clear and systematic structural classification of Polynesian societies, an achievement that Raymond Firth also found "interesting" and having "the merit of clear statement." Firth, however, had "reservations" about 
the ramage/descent-line distinction, which led him to consider the underlying ecological correlations "rather artificial." "Though unconvinced by this argument as well, Goodenough found it methodologically "a valuable contribution" and backed Sahlins's criticisms of the most important alternative comparativist thesis of the I950s, Irving Goldman's theory of status rivalry, for its lack of clarity and rigor. ${ }^{7}$ In a dramatic exemplification of his own theory, Goldman was later to lay against Social Stratification's author the most cutting accusation a leftwing materialist evolutionist could endure, that of being functionalist. ${ }^{8}$

I have referred to a certain flatness of the prose in Social Stratification. Before long, however, a different Sahlins style began to emerge, one of the more distinctive and quirky voices in contemporary anthropology. Five years after the publication of Social Stratification, a famous and much reprinted extension of its basic approach appeared - a nominally comparativist and materialist essay on forms of Oceanic leadership with the punning title of "Poor Man, Rich Man, Big-Man, Chief." In this essay, Sahlins cites Social Stratification sparingly and the first footnote jokingly christens his new and looser approach the "Method of Uncontrolled Comparison." Ecological adaptation was still the primary explanatory variable but it is tempting to read Sahlins's later transition to culturalist explanations as a response to the growing recognition that differences between Melanesia and Polynesia also reflected vernacular cosmologies of power. In many respects, "Poor Man, Rich Man" represents the high-water mark in Pacific sociocultural anthropology of the kind of explanation Sahlins proposed in Social Stratification. Although Social Stratification is not as widely read as the later essay, it remains a serious and widely acknowledged statement of a particular position. The materialist and evolutionist banner, however, has since mostly been kept flying by prehistorians and archaeologists.

\section{Historical Metaphors and Mythical Realities}

Sahlins's insights in the Ig63 essay and his increasing disavowal of evolutionist materialism culminated in ideas first aired in two talks delivered in I979. One was a keynote address to the Congress of the Australian and New Zealand Association for the Advancement of Science, published as Sahlins's arguably second most famous essay, "The StrangerKing." 10 sing an approach he labels "processual structuralism" and couched in occasionally baroque language, this piece applied insights 
from the work of the great historical linguist of Indo-European myth and society, Georges Dumézil. Sahlins argued that Polynesian kingship represented a kind of savagery best conceptualized as originating from outside society and perpetually absorbed by locals through a variety of processes that linked history and structure.

The other I979 talk was the ASAO Distinguished Lecture that was to appear in expanded form as Historical Metaphors and Mythical Realities. My earlier mention of the continuity of Sahlins's political interests, as well as their change in tone, resonates in a poignant sentence from the preface. His history, he states, "cannot claim to be Marxist, but it has the same minimum and sufficient premises: that men and women are suffering beings because they act at once in relationship to each other and in a world that has its own relationships" (vii).

He begins his monograph by questioning a persistent theoretical contrast between structure and history. The structural linguistics tradition recommends the analysis of structure by means of a synchronic approach (in which phenomena are treated as existing at one and the same moment in time, or even as existing outside time). History, on the other hand, requires a diachronic approach (in which phenomena are treated as existing in and through time). ${ }^{11}$ On this view, structural anthropology has no business with history. For Sahlins, however, the theoretical rigor that this exclusion brings risks the loss of "what anthropology is all about," which is to say "practice-human action in the world" (6). How, then, to reconcile structure and history? By showing "that history is organized by structures of significance" or, to put it another way, "ordered by culture"; and, further, by showing how "in that process, the culture is reordered." The introduction closes with the question, "How does the reproduction of a structure become its transformation?" (8).

Sahlins answers with the provocative assertion that Hawailan history repeats itself as event only after its initial appearance as myth, in which individual persons take on the character of their ancestral leaders and collective identity. Historical accounts of the explorer Vancouver's attempts to convert a Hawaiian chief to Christianity in the late eighteenth century turn out to reenact a myth based on "annual ritual alternation of the gods Lono and Ku" (II). Lono was the god of peace, fertility, and productivity, who reigned during the four-month period called the Makahiki; $\mathrm{Ku}$, the god of warfare and human sacrifice, held sway the rest of the year. The opposition between them reflected a divi- 
sion based on original reproductive powers in the maternal line and the violent transgressive usurpation of those powers by an invading male (the "stranger-king" of Dumézil's theory, to which Sahlins makes reference in Historical Metaphors, I4).

All this sets the stage for a "cosmological drama" (17). The Hawaiian interpretation of the arrival of Captain Cook in early 1779 at the big island of Hawai'i equated Cook with Lono. Sahlins claims that this view was not only well attested in the historical record but also expressive of cultural logic. During the Makahiki, priests carried an image of Lono on a clockwise circuit of the island, which happens to be the direction in which Cook's ships circumnavigated the island before he landed at Kealakekua Bay. Moreover, the ships ran parallel to, and at roughly the same speed as, the shore-bound procession. Kealakekua happened to be the site of an important temple devoted to Lono where, according to tradition, his circuit of the island began and ended each year (I8-22). The rituals by which Cook was received and one of his sailors was buried, the fact that the British were allowed to take away the temple's wooden fence and images to use as fuel, the gifts made by the British of tools and other objects made of iron, the enormous hospitality (in terms of food and sexual services) provided by the Hawaiians, Cook's fortuitous announcement that he would leave soon as the Makahiki came to an end and that he would return in a year's time-all of these events brought together a historical sequence and a ritual calendar.

The time of $\mathrm{Ku}$ was at hand, as represented by the recent arrival of Kalaniopu'u, the paramount chief of Hawai' $i$. The cosmological drama was confirmed by the ships' departure on schedule. Unfortunately for Cook, his ships returned a week later because one of them had sprung a foremast. The cool welcome they received, in contrast to the earlier exuberant one, showed that Cook had disturbed the ritual categories. Incidents of theft and violence by the locals increased and chiefs could not be persuaded to keep their subjects under control. Cook's premature return posed a threat to the resurgent power of $\mathrm{Ku}$ and, when he tried to take Kalaniopu'u hostage as a bargaining chip for the return of a stolen cutter (ship's boat), a hostile group attacked and killed him. Some of his remains were handed over to the stunned British survivors while others were later claimed to have been incorporated into the cult of Lono.

The death and subsequent installation of Cook as a cult figure fit with Hawaiian ideas about chiefly succession and the absorption of dead chiefs into local genealogies by conquering ones. Through a complex 
system of historical transformations, Kamehameha, the chief who was to establish unified and dynastic control over the Hawaiian archipelago by the end of the eighteenth century, took this absorption a step further by seeking a special connection to the British monarchy and welcoming British tracle. Thus was "the theory of the Makahiki transposed by the death of Cook into a register of practice" (27). The trade goods introduced into this world, as well as the earlier objects exchanged between Cook's voyagers and the locals, became a way of reinforcing and reshaping the hierarchical separation between chiefs and commoners $(29-3 \mathrm{I}$ and chap. 3, "Transformation"). ${ }^{12}$ Embroiled in notions of tapu, changes in the status of chiefs also led to a transformation of relations between different lines of chiefs, between men and women, and between Hawaiians and outsiders. It was this detailed reinterpretation of the evidence in terms of an imputed Hawaiian version of mytho-history that went beyond the existing historical accounts by J. C. Beaglehole and Gavan Daws. ${ }^{13}$ Sahlins's approach turns the spotlight back on Western forms of historical thought as themselves irreducibly cultural modes of understanding.

Sahlins's short monograph clearly addressed issues of concern to historians of Hawai $i$ as well as to those who wanted to understand the importance of cultural difference in early encounters between Western explorers and Pacific peoples. Not all specialists in the region agreed with his interpretations, but the debate did not stray much beyond the pages of regional journals. ${ }^{14}$

What brought Historical Metaphors to wider attention was Obeyesekere's famous attack on the idea of the apotheosis of Captain Cook. Obeyesekere, a Sri Lankan anthropologist whose own field research had been carried out in South Asia, was new to Pacific Studies but drawn into the argument by what he saw as a fallacy. The view that Hawaiians had received Cook as the god Lono struck Obeyesekere as a Western fantasy routinely found in explorers' accounts of their reception by "natives." Were such notions inventions, he asked, "based on prior "myth models' in Europe's antecedent history"? 15 All the trappings of veneration toward the white explorer could be explained in terms of universal standards of economic and political rationality.

In support of his surmise that Cook was not Lono he pointed to the fact that the great navigator was made to take part in rituals honoring Lono. At best, then, Cook was installed as a chief, and his deification, if it took place at all, occurred after his death, not before. Now Obeye- 
84 MICHAEL GOLDSMITH

sekere conflates two issues here: whether deification occurs before or after death and whether it occurs to an insider or an outsider. His interpretation of the latter (that, on the basis of South Asian evidence, outsiders are rarely if ever deified) is probably influenced by caste-like notions of purity, which aim to defend the boundaries of the group against pollution; for Sahlins, however, the Polynesian logic of hierarchy works in an opposite fashion, by allowing or even requiring chiefs, conceived as "outside" society, to achieve power.

\section{Conclusion}

No brief description of this debate can convey the passion and even anger of Sahlins's responses to Obeyesekere's criticism. Indeed, in two recent essays, ${ }^{16}$ Sahlins has launched a further attack on Obeyesekere's thesis that narratives of "savage" cannibalism are another fabulist form of Western obsession with natives, whose main role is to fulfill certain fantasies of colonizing cultures. ${ }^{17}$ Despite the fact that Sahlins dismisses Obeyesekere's contributions as "artificially maintained controversies," there seems little doubt that he in turn will continue to fuel the antagonism if provoked.

Will one of these two anthropological heavyweights score a knockout? Most Pacific specialists see Sahlins as leading on points because of his superb command of rhetoric in argument, his vast erudition in the Hawaiian and Fijian historical archives, and his grasp of the ethnographic context based on his own fieldwork. These are formidable strengths. Even in the unlikely event that he has to concede on some matters of interpretation, there is little chance of him throwing in the towel to his younger and taller opponent.

Two lessons, then, can be drawn from the evolution of Marshall Sahlins over the half century of his career so far. The first is that he commits himself passionately to the arguments he puts forward and defends them vigorously when he believes that his views have been misrepresented or that his attackers have not put in the training and preparation that he has. The second is that he is perfectly capable of changing the grounds of his argument, as the clear theoretical differences between Social Stratification in Polynesia and Historical Metaphors and Mythical Realities reveal. And yet such major rethinks may occur no more than once in a lifetime. Almost a quarter of a century after he reached the pinnacle of materialist explanation and then turned to a new way of under- 
standing Pacific cultural history, the present-day Sahlins shows no signs of undergoing a theoretical conversion similar to the one he went through then. If he ever does so, my reading of his work's trajectory suggests that he will do so not by publicly disowning his earlier stance but by moving to a new position on his own terms and in his own time. There will be no concession speech.

\section{Notes}

I. Gananath Obeyesekere, The Apotheosis of Captain Cook: European Mythmaking in the Pacific (Princeton, 1992); Marshall D. Sahlins, How "Natives" Think: About Captain Cook, For Example (Chicago, 1995).

2. Sahlins, "What is Anthropological Enlightenment? Some Lessons of the Twentieth Century," Annual Review of Anthropology 28 (1999): i-xxiii; and the revised version of this essay published as "On the Anthropology of Modernity; or, Some Triumphs of Culture over Despondency Theory," in Culture and Sustainable Development in the Pacific, ed. Antony Hooper (Canberra, 2000).

3. See Niel Gunson, "An Introduction to Pacific History," in Pacific Islands History: Journeys and Transformations, ed. Brij V. Lal (Canberra, 1992), I2.

4. Antony B. Hooper, "Socio-Economic Organization of the Tokelau Islands," VITlth Congress of Anthropological and Ethnological Sciences, Proceedings, vol. 2. (1970), 238-40; Judith Huntsman and Antony Hooper, Tokelau: A Historical Ethnography (Auckland, 1996).

5. Sahlins, "Production, Distribution, and Power in a Primitive Society," in Cultures of the Pacific, ed. Thomas G. Harding and Ben J. Wallace (New York, 1970), 78-84 (originally published in 1960); idem, Moala: Culture and Nature on a Fijian Island (Ann Arbor, 1962).

6. Ian Hogbin, Oceania 30, no. I (1959): 79-80; Ward Goodenough, Journal of the Polynesian Society 68, no. 3 (1959): 255-58; Raymond Firth, American Anthropologist 63 , no. 3 (1961): 610-12.

7. Irving Goldman, "Status Rivalry and Cultural Evolution in Polynesia," American Anthropologist 57, no. 4 (1955): 680-97.

8. Irving Goldman, Ancient Polynesian Society (Chicago, 1970), 23, 481. This accusation rests on a major progressive political criticism of functionalism, that it upholds and justifies continuity over change by treating societies ahistorically. Given Sahlins's concern for evolutionary change, the charge is unconvincing but it still would have stung.

9. Sahlins, "Poor Man, Rich Man, Big-Man, Chief: Political Types in Melanesia and Polynesia," Comparative Studies in Society and History 5, no. 3 (1963): 285-303.

1o. Sahlins, "The Stranger-King: Dumézil among the Fijians," Journal of Pacific History 16, no. 3 (1981): 107-32. 
II. The founding text for the synchrony/diachrony distinction is Ferdinand de Saussure's Course in General Linguistics (New York, I959, but first published in French over forty years before).

12. See also Sahlins, "The Political Economy of Grandeur in Hawaii from I810 to 1830," in Culture through Time: Anthropological Approaches, ed. Emiko OhnukiTierney (Stanford, 1990), 26-56.

I3. J. C. Beaglehole, "The Death of Captain Cook," Historical Studies, Australia and $N_{e w}$ Zealand I1, no. 43 (1964):289-305; Gavan Daws, "Kealakekua Bay Revisited: A Note on the Death of Captain Cook," Journal of Pacific History 3 (1968): $21-23$.

I4. See, for example, Steen Bergendorff, Ulla Hasager, and Peter Henriques, "Mythopraxis and History: On the Interpretation of the Makahiki," Journal of the Polynesian Society 97, no. 4 (1988): 39I--408; Christine Ward Gailey, "Categories without Culture: Structuralism, Ethnohistory and Ethnocide," Dialectical Anthropology 8, no. 3 (1983): 24I-50; Marshall D. Sahlins, "Captain Cook at Hawaii," Journal of the Polynesian Society 98, no. 4 (1989): $371-423$.

15. Gananath Obeyesekere, The Apotheosis of Captain Cook: European Mythmaking in the Pacific (Princeton, I992), 8.

16. Sahlins, "Artificially Maintained Controversies: Global Warming and Fijian Cannibalism," Anthropology Today i9, no. 3 (2003): 3-5; idem, "Artificially Maintained Controversies (Part 2)," Anthropology Today I9, no. 6 (2003): 2 I-23.

17. Obeyesekere, "British Cannibals: Contemplation of an Event in the Death and Resurrection of James Cook, Explorer," Critical Inquiry I8, no. 4 (1992): 630-54; idem, "Cannibal Feasts in Nineteenth-Century Fiji: Seamen's Yarns and the Ethnographic Imagination," in Cannibalism and the Colonial World, ed. Francis Barker, Peter Hulme, and Margaret Iversen (Cambridge, 1998), 63-86; idem, "Narratives of the Self: Chevalier Peter Dillon's Fijian Cannibal Adventures," in Body Trade: Captivity, Cannibalism and Colonialism in the Pacific, ed. Barbara Creed and Jeanette Hoorn (New York/Dunedin, 200I), 69-II I; idem, "Comment: Cannibalism Reconsidered," Anthropology Today 10, no. 5 (2003): 18. 